\section{(2) \\ BRAZIILIAN JOURNAL \\ OF MEDICAL AND BIOLOGICAL RESEARCH}

www.bjournal.com.br
ISSN 0100-879X

Volume 45 (6) 473-564 June 2012

BIOMEDICAL SCIENCES

AND

CLINICAL INVESTIGATION

Braz J Med Biol Res, May 2012, Volume 45(6) 473-481

doi: $10.1590 / \mathrm{S} 0100-879 X 2012007500050$

Electron paramagnetic resonance study of lipid and protein membrane components of erythrocytes oxidized with hydrogen peroxide

S.A. Mendanha, J.L.V. Anjos, A.H.M. Silva and A. Alonso

The Brazilian Journal of Medical and Biological Research is partially financed by

\section{Q QNPPq}

Ministério da Ciência e Tecnologia

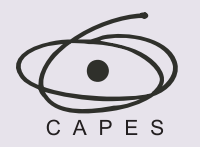

Ministério da Educação

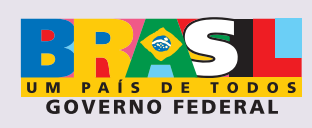

DTFAPESP

Institutional Sponsors

† SHIMADzu

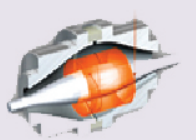

Associaçăo

Explore High - Performance MS Orbitrap Technology

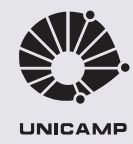




\title{
Electron paramagnetic resonance study of lipid and protein membrane components of erythrocytes oxidized with hydrogen peroxide
}

\author{
S.A. Mendanha, J.L.V. Anjos, A.H.M. Silva and A. Alonso \\ Instituto de Física, Universidade Federal de Goiás, Goiânia, GO, Brasil
}

\begin{abstract}
Electron paramagnetic resonance (EPR) spectroscopy of spin labels was used to monitor membrane dynamic changes in erythrocytes subjected to oxidative stress with hydrogen peroxide $\left(\mathrm{H}_{2} \mathrm{O}_{2}\right)$. The lipid spin label, 5-doxyl stearic acid, responded to dramatic reductions in membrane fluidity, which was correlated with increases in the protein content of the membrane. Membrane rigidity, associated with the binding of hemoglobin $(\mathrm{Hb})$ to the erythrocyte membrane, was also indicated by a spinlabeled maleimide, 5 -MSL, covalently bound to the sulfhydryl groups of membrane proteins. At $2 \%$ hematocrit, these alterations in membrane occurred at very low concentrations of $\mathrm{H}_{2} \mathrm{O}_{2}(50 \mu \mathrm{M})$ after only 5 min of incubation at $37^{\circ} \mathrm{C}$ in azide phosphate buffer, $\mathrm{pH}$ 7.4. Lipid peroxidation, suggested by oxidative hemolysis and malondialdehyde formation, started at $300 \mu \mathrm{M} \mathrm{H}_{2} \mathrm{O}_{2}$ (for incubation of $3 \mathrm{~h}$ ), which is a concentration about six times higher than those detected with the probes. Ascorbic acid and a-tocopherol protected the membrane against lipoperoxidation, but did not prevent the binding of proteins to the erythrocyte membrane. Moreover, the antioxidant (+)-catechin, which also failed to prevent the cross-linking of cytoskeletal proteins with $\mathrm{Hb}$, was very effective in protecting erythrocyte ghosts from lipid peroxidation induced by the Fenton reaction. This study also showed that EPR spectroscopy can be useful to assess the molecular dynamics of red blood cell membranes in both the lipid and protein domains and examine oxidation processes in a system that is so vulnerable to oxidation.
\end{abstract}

Key words: Electron paramagnetic resonance; Spin label; Erythrocyte; Membrane fluidity; Membrane oxidation; Protein oxidation

\section{Introduction}

Red blood cells (RBCs) are continuously exposed to reactive oxygen species (ROS) produced as a result of their high cellular oxygen concentration and abundant heme iron content (1). The autoxidation of oxyhemoglobin to methemoglobin generating superoxide anion radical $\left(\mathrm{O}_{2}{ }^{-}\right)$represents the main source of ROS in RBCs (2). Hydrogen peroxide $\left(\mathrm{H}_{2} \mathrm{O}_{2}\right)$ is produced by $\mathrm{O}_{2}$ - $^{-}$dismutation, which causes oxidative modifications in oxyhemoglobin (3). Exposure of oxyhemoglobin to $\mathrm{H}_{2} \mathrm{O}_{2}$ leads to increased concentration of methemoglobin, lipid peroxidation (4), and spectrin-hemoglobin $(\mathrm{Hb})$ complexes (5). In addition, the erythrocyte membrane is particularly sensitive to oxidative damage due to its high polyunsaturated fatty acid content, and hence, it represents an important system to study the effect of oxidative stress $(6,7)$. In this respect, RBCs have been used as a model for the assessment of oxidative damage caused by a variety of inducers such as $\mathrm{H}_{2} \mathrm{O}_{2}, \mathrm{Cu}^{2+}$-ascorbic acid, $\mathrm{Fe}^{2+}$-ascorbic acid, azo compounds, and the xanthine/ xanthine oxidase system (4,7-9).

Several studies using fluorescence spectroscopy $(4,9)$, scanning electron microscopy (SEM) $(2,5,8)$ and spectrophotometry $(10,11)$ have suggested that oxidative damage promoted by ROS may be mitigated by antioxidants. In particular, many studies have reported protective effects of dietary antioxidants against $\mathrm{H}_{2} \mathrm{O}_{2}$-induced oxidation in human RBCs. For instance, preincubation of human erythrocytes with a red wine extract significantly prevents oxidative hemolysis, methemoglobin production and lipid peroxidation induced by $\mathrm{H}_{2} \mathrm{O}_{2}$ (4). Similarly, peel extracts from unripened and ripened mango fruits have protective effects on $\mathrm{H}_{2} \mathrm{O}_{2}$-induced hemolysis, lipid peroxidation, membrane protein degradation, and morphological alteration of human RBCs detected by SEM (11),

Correspondence: A. Alonso, Instituto de Física, Universidade Federal de Goiás, Goiânia, GO, Brasil. Fax: +55-62-3521-1014.

E-mail: alonso@if.ufg.br

Received November 9, 2011. Accepted March 26, 2012. Available online April 5, 2012. Published June 4, 2012. 
and potato peel extracts have provided protection against $\mathrm{H}_{2} \mathrm{O}_{2}$-induced morphological changes in rat RBCs (7).

Electron paramagnetic resonance (EPR) spectroscopy of spin labels has been used to access dynamic molecular changes in cell membranes due to lipid and protein oxidation. Membrane rigidity associated with increased malondialdehyde (MDA) formation was found in apical segments of coffee seedling roots after chilling stress $(12,13)$, in mitochondria subjected to iron-induced lipoperoxidation (14), in lead-exposed HepG2 cells (15) and in sonicated soybean phospholipid vesicles upon lipoperoxidation with iron/ascorbate (16). Oxidative stress of the integral proteins of cell membranes reduces the mobility of the protein backbone, which has been monitored using thiol-specific spin labels (17-19). In the present study, we have detected dramatic stiffening in the erythrocyte membrane of cells subjected to oxidative stress with $\mathrm{H}_{2} \mathrm{O}_{2}$, in the presence of azide, which was correlated with an increase in the protein content of the membrane. Surprisingly, membrane alterations were observed at seversl times lower $\mathrm{H}_{2} \mathrm{O}_{2}$ concentrations and incubation than necessary for oxidative hemolysis and thiobarbituric acid reactive species (TBARS) formation. To examine this oxidative process in more detail, we also analyzed the protective effects of three classic antioxidants on the physicochemical changes induced by free radical stress in both lipid and protein components of the RBC membrane.

\section{Material and Methods}

\section{Chemicals}

The spin labels, 5-doxyl stearic acid (5-DSA) and 3-maleimide-proxyl (5-MSL), were purchased from Sigma (USA), whereas all other reagents were purchased from either Sigma or Merck S.A. (Brazil). All solutions were prepared with Milli-Q water.

\section{Preparation of erythrocytes and induction of oxidative stress}

Human blood samples obtained from two blood banks in Goiânia, Brazil, were diluted in phosphate-buffered saline (PBS, $10 \mathrm{mM}$ phosphate, $150 \mathrm{mM} \mathrm{NaCl}, \mathrm{pH} 7.4$ ) containing $1 \mathrm{mM}$ sodium azide and centrifuged three times at $150 \mathrm{~g}$ for $10 \mathrm{~min}$ at $4^{\circ} \mathrm{C}$. Plasma and white blood cells were carefully removed by aspiration in each wash. Oxidative stress was induced in the erythrocytes at $2 \%$ hematocrit in PBS with the desired concentration of $\mathrm{H}_{2} \mathrm{O}_{2}$ and incubation at $37^{\circ} \mathrm{C}$ for $3 \mathrm{~h}$. The reagent solutions were gently shaken every 30 min during incubation. To evaluate the protective effect of antioxidant molecules, RBCs were previously incubated for $30 \mathrm{~min}$ at $37^{\circ} \mathrm{C}$ with the desired concentrations of ascorbic acid, (+)-catechin, L-carnosine, or $\alpha$-tocopherol before the oxidation process. In tests that measured the antioxidant effect of catalase, sodium azide was not added to the PBS.

\section{Determination of hemolysis}

The hemolytic level was determined spectrophotometrically. After the sample was oxidized by following the experimental protocol described above, the reagent solutions were centrifuged for $10 \mathrm{~min}$ at $300 \mathrm{~g}$ and at $25^{\circ} \mathrm{C}$ and the absorption of the supernatant $(A)$ was measured at $540 \mathrm{~nm}$. Percent RBC lysis was determined according to the following equation: $\%$ hemolysis $=A_{a}-A_{c 1} / A_{c 2}-$ $A_{c 1}$, where $A_{c 1}$ is the control sample $\left(0 \% \mathrm{H}_{2} \mathrm{O}_{2}\right), A_{c 2}$ is the sample completely hemolyzed with Milli- $Q$ water and $A_{a}$ is the sample with the desired $\mathrm{H}_{2} \mathrm{O}_{2}$ concentration.

\section{Determination of TBARS}

MDA production was measured according to the following protocol (20). After incubating the RBCs in solutions containing $\mathrm{H}_{2} \mathrm{O}_{2}, 10 \%$ trichloroacetic acid (TCA (w/v) final concentration) was added to $1.5 \mathrm{~mL}$ of the supernatant solution of erythrocytes. The solutions were then centrifuged for $10 \mathrm{~min}$ at $300 \mathrm{~g}$ and $1 \mathrm{~mL}$ thiobarbituric acid (TBA, 1\% in $0.05 \mathrm{M} \mathrm{NaOH}$ ) was added to the supernatant. The reagent solution was heated to $95^{\circ} \mathrm{C}$ for $30 \mathrm{~min}$. After cooling to $4^{\circ} \mathrm{C}, 1 \mathrm{~mL}$ n-butanol was added to each tube to extract the MDA-TBA complex. TBARS concentration was obtained by subtracting $20 \%$ of the absorbance at $453 \mathrm{~nm}$ from the absorbance at $532 \mathrm{~nm}$, using a molar extinction coefficient of $1.56 \times 10^{5} \mathrm{M}^{-1} \mathrm{~cm}^{-1}$.

\section{Spin labeling of lipid and protein components of the erythrocyte membrane}

After exposure to oxidative stress, the erythrocytes were sedimented by a 10 -min centrifugation at $300 \mathrm{~g}$ and $4^{\circ} \mathrm{C}$. The lipid component of the membrane was spin labeled by adding $\sim 1 \mu \mathrm{L} 5-\mathrm{DSA}$ ( $5 \mathrm{mg} / \mathrm{mL}$ in ethanol) to the RBC pellet. Maleimide labeling of erythrocyte membranes was performed by first incubating the samples in $5 \mathrm{mM}$ phosphate, $\mathrm{pH} 8.0$, for $2 \mathrm{~h}$ at $4^{\circ} \mathrm{C}$, centrifuging for $30 \mathrm{~min}$ at $20,000 \mathrm{~g}$ and $4^{\circ} \mathrm{C}$, and carefully removing the supernatant. This procedure was repeated until the supernatant was free of residual hemoglobin. Then, $\sim 2 \mu \mathrm{L} 5-\mathrm{MSL}(50 \mathrm{mg} / \mathrm{mL}$ in ethanol) was added to the membranes and was allowed to react for $30 \mathrm{~min}$ at $4^{\circ} \mathrm{C}$. The unbound label was removed by centrifugation.

\section{Preparation, oxidation and spin labeling of erythrocyte ghosts}

Erythrocytes at $\sim 6 \%$ hematocrit were incubated in $5 \mathrm{mM}$ PBS, pH 8.0, for $2 \mathrm{~h}$ at $4^{\circ} \mathrm{C}$. After a 30-min centrifugation at $20,000 \mathrm{~g}$ and $4^{\circ} \mathrm{C}$, the supernatant was carefully removed. The above procedure was repeated until the supernatant was free of residual $\mathrm{Hb}$. The erythrocyte ghosts were then resuspended in PBS. To induce oxidative stress, $2 \mathrm{mM} \mathrm{H}_{2} \mathrm{O}_{2}$ and $200 \mu \mathrm{M} \mathrm{FeSO}_{4}$ in $150 \mathrm{mM} \mathrm{NaCl}, \mathrm{pH} 7.0$, were added to the ghost suspension and incubated at $37^{\circ} \mathrm{C}$ for $1 \mathrm{~h}$. To evaluate the protective effect of $(+)$-catechin, erythrocyte ghosts were preincubated for $30 \mathrm{~min}$ at $37^{\circ} \mathrm{C}$ with the de- 
sired aliquot of this antioxidant molecule and subjected to oxidative stress as described above.

\section{Protein quantification of oxidized erythrocyte membranes}

The protein content of the membrane of oxidized erythrocytes was measured using a commercial kit (Sigma) based on the reaction of bicinchoninic acid (BCA) $(21,22)$. After erythrocyte exposure to oxidative stress, erythrocyte ghosts were prepared and a small aliquot was added to a solution of BCA reagent. After incubation for $30 \mathrm{~min}$ at $37^{\circ} \mathrm{C}$, absorbance was measured at $562 \mathrm{~nm}$. The protein concentration was determined with a calibration curve prepared with bovine serum albumin (BSA).

\section{EPR spectroscopy}

EPR spectroscopy was performed with a Bruker ESP 300 spectrometer (Rheinstetten, Germany) equipped with an ER 4102 ST resonator and a Bruker temperature controller. The instrument settings were: microwave power of $2 \mathrm{~mW}$, modulation frequency of $100 \mathrm{KHz}$, modulation amplitude of $1.0 \mathrm{G}$, magnetic field scan of $100 \mathrm{G}$, sweep time of $168 \mathrm{~s}$, and detector time constant of $41 \mathrm{~ms}$. All measurements were performed at room temperature $\left(24-26^{\circ} \mathrm{C}\right)$.

\section{Results}

\section{Ascorbic acid and $\alpha$-tocopherol as inhibitors of $\mathrm{H}_{2} \mathrm{O}_{2}$-induced hemolysis and TBARS formation in RBCs}

The levels of $\mathrm{H}_{2} \mathrm{O}_{2}$-induced oxidative hemolysis measured at $2 \%$ hematocrit (Figure $1 \mathrm{~A}$ ) indicate that RBC damage occurs in the concentration range of 0.3 to $1 \mathrm{mM} \mathrm{H}_{2} \mathrm{O}_{2}$. The protective effects of the antioxidants, ascorbic acid and a-tocopherol, against oxidative hemolysis induced by $0.8 \mathrm{mM} \mathrm{H}_{2} \mathrm{O}_{2}$ (Figure 1B) show that ascorbic acid provided a maximum protective effect at concentrations around $160 \mu \mathrm{M}$, leading to almost no oxidative damage, whereas $\alpha$-tocopherol provided only a discrete effect at concentrations near $300 \mu \mathrm{M}$, with a reduction of the hemolytic level to about $30 \%$. TBARS levels increased significantly when erythrocytes were treated with $\mathrm{H}_{2} \mathrm{O}_{2}$ (Figure 1A). The protective effects of ascorbic acid and $\alpha$-tocopherol against the oxidative damage of RBC membranes were consistent with the results of protection against hemolysis (Table 1).

\section{Alteration in erythrocyte membrane fluidity \\ EPR spectra of 5-DSA in erythrocyte membranes previ- ously exposed to different $\mathrm{H}_{2} \mathrm{O}_{2}$ concentrations (Figure 2A) demonstrate that the addition of $\mathrm{H}_{2} \mathrm{O}_{2}$ leads to an increase}

in membrane stiffness as indicated by the spectral EPR parameter $2 \mathrm{~A}_{/ /}$. The behavior of $2 \mathrm{~A}_{/ /}$with the oxidative stress induced by $\mathrm{H}_{2} \mathrm{O}_{2}$ at $2 \%$ hematocrit is shown in Figure $2 \mathrm{~B}$. Membrane fluidity assessed by the $2 \mathrm{~A}_{/ /}$parameter results in a sigmoidal curve as in the case of the hemolytic effect (Figure 1A), but the changes in membrane fluidity were initiated at $\mathrm{H}_{2} \mathrm{O}_{2}$ concentration of about $50 \mu \mathrm{M}$, which is approximately six times lower than for the hemolytic effect $(\sim 300 \mu \mathrm{M})$. Also, the antioxidants ascorbic acid and a-tocopherol at concentrations that were protective against hemolysis (Figure 1B) did not show any ability to prevent changes in erythrocyte membrane fluidity. Furthermore, the oxidation process triggered by $\mathrm{H}_{2} \mathrm{O}_{2}$ occurred rapidly because the increase of the $2 \mathrm{~A}_{/ /}$parameter was observed after only 5 min of exposure to $\mathrm{H}_{2} \mathrm{O}_{2}$ and could not be prevented
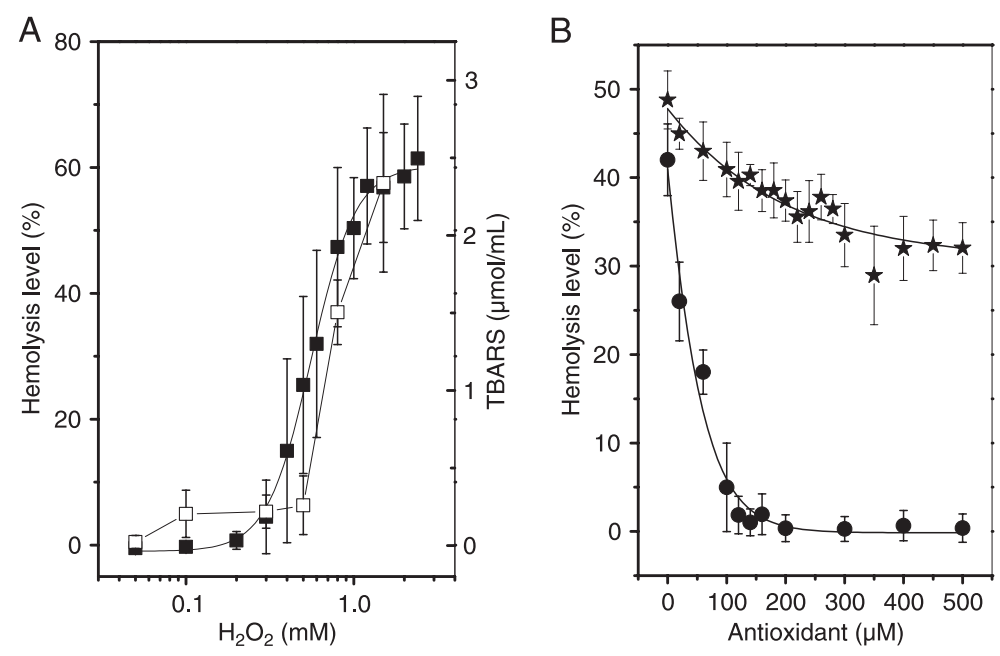

1. Percent hemolysis (filled squares) and TBARS (open squares) induced (Panel A). Protective effects of ascorbic acid (circles) and a-tocopherol (stars) on percent hemolysis induced by $0.8 \mathrm{mM} \mathrm{H}_{2} \mathrm{O}_{2}($ Panel $B)$. TBARS $=$ thiobarbituric acid reactive species.

Table 1. Production of thiobarbituric acid reactive species (TBARS) in erythrocyte suspensions with $0.8 \mathrm{mM} \mathrm{H}_{2} \mathrm{O}_{2}$ and protective effect of ascorbic acid and $\alpha$-tocopherol at several concentrations.

\begin{tabular}{ccc}
\hline Antioxidant $(\mu \mathrm{M})$ & \multicolumn{2}{c}{ TBARS $(\mu \mathrm{mol} / \mathrm{mL})$} \\
\cline { 2 - 3 } & Ascorbic acid & a-tocopherol \\
\hline 0 & $1.44 \pm 0.21$ & $1.44 \pm 0.21$ \\
20 & $0.53 \pm 0.25$ & - \\
60 & $0.49 \pm 0.14$ & - \\
100 & - & $1.35 \pm 0.28$ \\
160 & $0.54 \pm 0.15$ & - \\
200 & - & $1.32 \pm 0.20$ \\
300 & - & $1.03 \pm 0.28$ \\
\hline
\end{tabular}


by well-known antioxidants such as ascorbic acid and (+)-catechin.

The results presented above indicate that the membrane fluidity changes in RBCs oxidized with $\mathrm{H}_{2} \mathrm{O}_{2}$ were caused by the membrane protein component. The formation of cross-links between spectrin and oxidized $\mathrm{Hb}$ (5) and/or the binding of hemichromes in the membrane (23) could alter the microenvironment around the spin probe and reduce its rotational motion. It is well known that integral membrane proteins restrict the motion of spin-labeled lipids that surround their hydrophobic regions in the membrane interior $(24,25)$. Thus, the restricted motion of the lipid spin probe in the membrane upon oxidative stress could be explained by alterations in the protein component of the membrane. To examine the probable relationship between the observed reduction in membrane fluidity and the binding of $\mathrm{Hb}$ to the membrane, an experiment measuring protein content as a function of $\mathrm{H}_{2} \mathrm{O}_{2}$ concentrations was performed (Figure 3). A correlation between an increase in total protein concentration in erythrocyte membranes and the reduction in membrane fluidity caused by gradual increases in $\mathrm{H}_{2} \mathrm{O}_{2}$ concentration was observed (Figure 3).

\section{Oxidation of erythrocyte membrane proteins}

To examine the dynamic changes in erythrocyte membrane proteins, the thiol-specific spin label, 5-MSL, was used. The EPR spectra of 5-MSL attached to sulfhydryl groups of RBC membrane proteins previously exposed to different $\mathrm{H}_{2} \mathrm{O}_{2}$ concentrations are shown in Figure 4A. EPR spectra of nitroxide side chains are generally characterized by the coexistence of two spectral components, indicating two probe populations with different states of mobility in thermodynamic equilibrium (26-28). Therefore, each 5-MSL spectrum is the overlap of two spectral components denoted $S$ (strongly immobilized) and W (weakly immobilized).
A

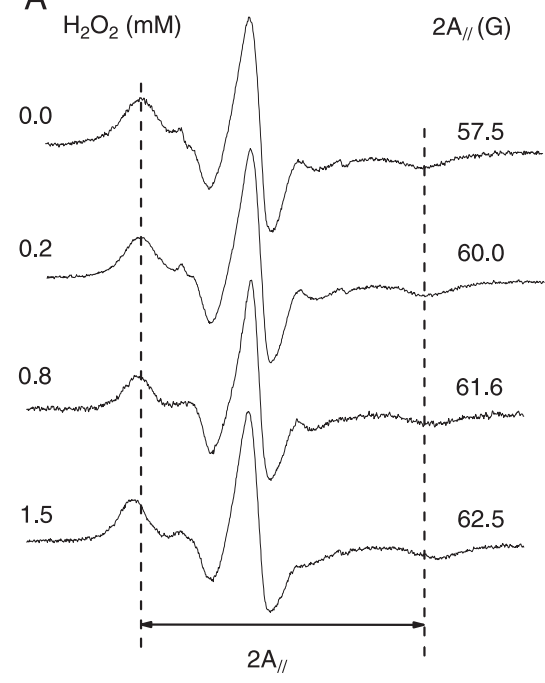

B

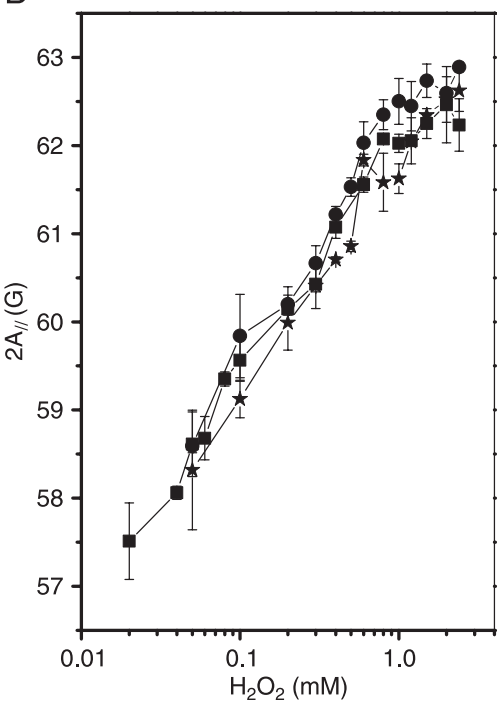

Figure 2. $A$, Electron paramagnetic resonance (EPR) spectra of 5-doxyl stearic acid in erythrocyte membranes in the presence of gradually increasing $\mathrm{H}_{2} \mathrm{O}_{2}$ concentrations. The vertical dotted lines are references for the control value of the $2 A_{/ /}$parameter, the outer hyperfine splitting. The total scanning range of the magnetic field of all spectra was $100 \mathrm{G}$. B, EPR parameter, $2 \mathrm{~A}_{/ /}$, for the control (squares), the $160-\mu \mathrm{M}$ ascorbic acidtreated (circles) and the 300- $\mu \mathrm{M}$ a-tocopherol-treated (stars) samples as a function of $\mathrm{H}_{2} \mathrm{O}_{2}$ concentration.

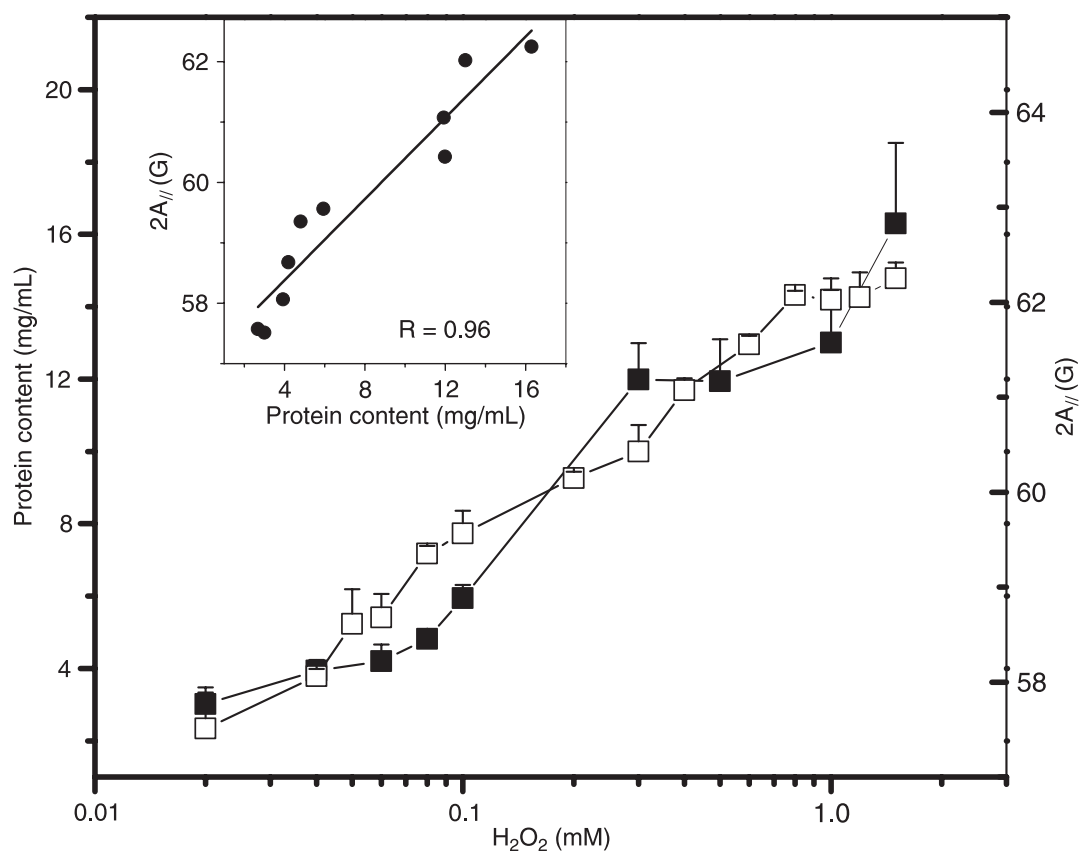

Figure 3. Protein content of the erythrocyte membranes (filled squares) and the electron paramagnetic resonance parameter, $2 \mathrm{~A}_{/ /}$, of 5 -doxyl stearic acid in the erythrocyte membranes (open squares) as a function of $\mathrm{H}_{2} \mathrm{O}_{2}$ concentration. Insert, The linear correlation coefficient in the plot of protein content versus $2 A_{/ /}$was $R=0.96$. 
The S and W components are associated with restricted and less restricted motion of the nitroxide on the 9.4-GHz EPR time scale. Two parameters measured directly in the EPR spectra, W/S and 2A// (Figure $4 A$ ), are useful for monitoring the effect of rigidity on the protein. As shown in Figure $4 \mathrm{~B}$, the parameters $\mathrm{W} / \mathrm{S}$ and $2 \mathrm{~A}_{/ /}$indicate that $\mathrm{H}_{2} \mathrm{O}_{2}$ promotes the rigidity of membrane proteins with the effect starting at 60 $\mu \mathrm{M}$. The oxidative process of erythrocyte membrane proteins will probably cause the formation of complexes with oxidized $\mathrm{Hb}$ through intra- and interprotein crosslinkings, which restrict the segmental motions of the protein backbone $(5,23)$.

Furthermore, the increase in the signal intensity of 5-MSL during the oxidative process (Figure 5) indicates an increase in the number of $\mathrm{SH}$ groups that are accessible to the spin probe. An increase of membrane-bound $\mathrm{Hb}$ aggregates could explain the additional reactive sites because each $\mathrm{Hb}$ contributes its own free $\mathrm{SH}$ groups. The amount of accessible $\mathrm{SH}$ groups in the membrane increases with the gradual increase of $\mathrm{H}_{2} \mathrm{O}_{2}$ concentration
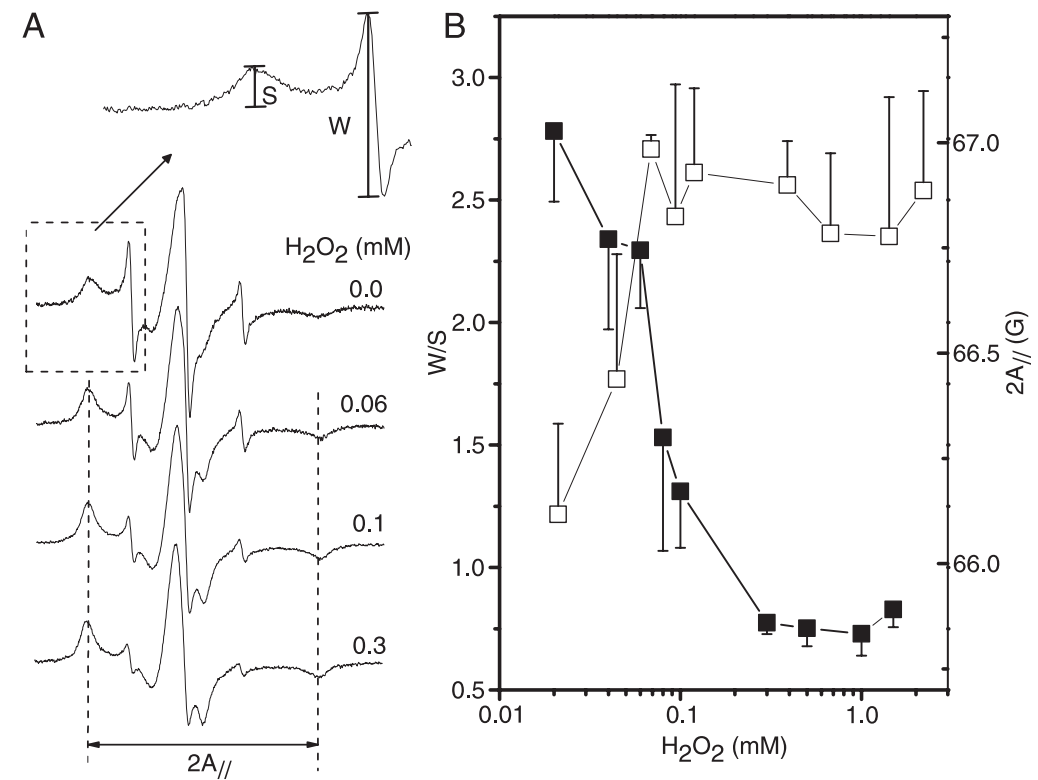

Figure 4. A, Electron paramagnetic resonance (EPR) spectra of 5-MSL bound to erythrocyte membrane proteins in the presence of gradually increasing $\mathrm{H}_{2} \mathrm{O}_{2}$ concentrations. The relative intensities of the resonance lines $\mathrm{S}$ and $\mathrm{W}$ (the fraction of labels in the strongly and weakly immobilized components, respectively) are related to protein dynamics, as well as the $2 A_{/ /}$parameter (the separation between the vertical dotted lines in the magnetic-field unit). $B$, The W/S intensity ratio (filled squares) and the electron paramagnetic resonance parameter $2 \mathrm{~A}_{/ /}$(open squares) plotted as a function of $\mathrm{H}_{2} \mathrm{O}_{2}$ concentration.

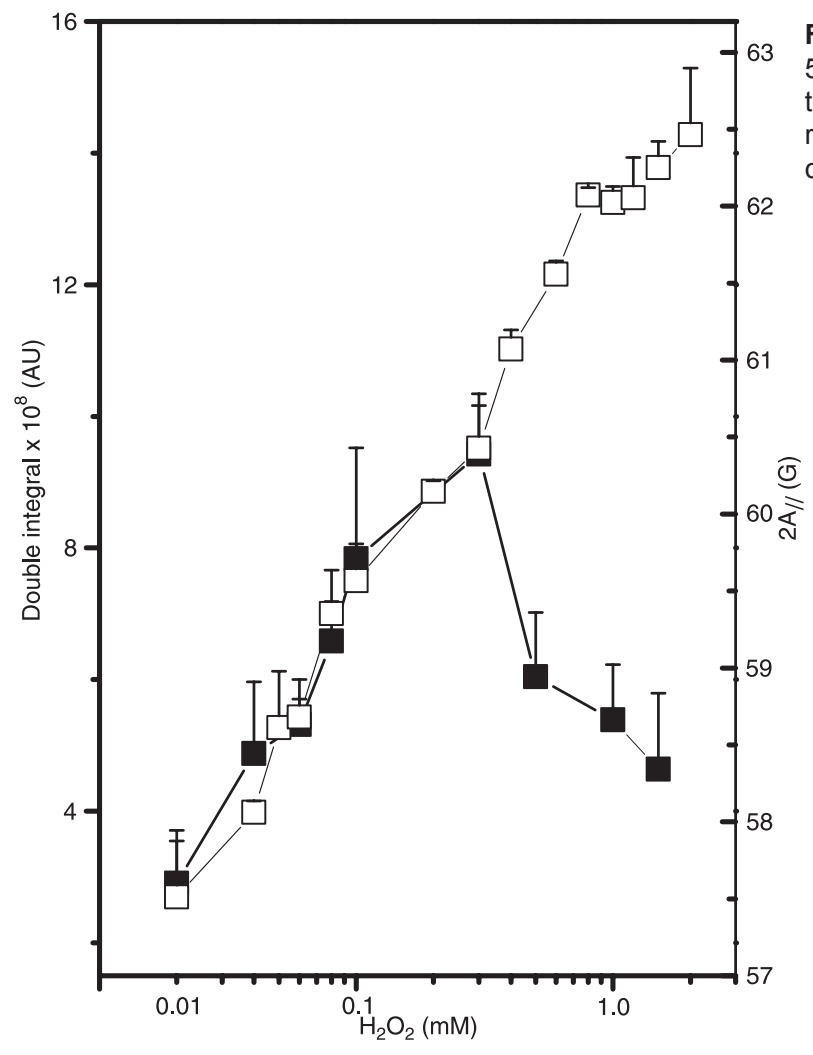

Figure 5. $\mathrm{H}_{2} \mathrm{O}_{2}$ concentration dependence of the signal intensity of 5-MSL attached to sulfhydryl groups of erythrocyte membrane proteins (open squares) and the electron paramagnetic resonance parameter, $2 \mathrm{~A} / /$, of the spin-labeled lipid, 5 -doxyl stearic acid, in erythrocyte membranes (filled squares). 
and is well correlated with the membrane protein content and the decrease of membrane fluidity as assessed by 5-DSA. Our results support the idea that cross-linking takes place between oxidized $\mathrm{Hb}$ and membrane proteins during the oxidation process induced by $\mathrm{H}_{2} \mathrm{O}_{2}$. However, above $0.3 \mathrm{mM} \mathrm{H}_{2} \mathrm{O}_{2}$ the amount of accessible $\mathrm{SH}$ groups is diminished, suggesting the occurrence of oxidation of these groups at higher $\mathrm{H}_{2} \mathrm{O}_{2}$ concentrations.

\section{Effect of azide}

In the present study, we used $1 \mathrm{mM}$ sodium azide in erythrocyte suspension to inhibit catalase. Without azide, the hemolytic levels are dramatically reduced, reaching a maximum of $5 \%$ over the entire range of measured $\mathrm{H}_{2} \mathrm{O}_{2}$ concentrations (Figure 6). In this case, the membrane rigidity was only observed at very high $\mathrm{H}_{2} \mathrm{O}_{2}$ concentrations (20 $\mathrm{mM}$ ), about two hundred times the $\mathrm{H}_{2} \mathrm{O}_{2}$ concentrations necessary to obtain similar membrane rigidity in the absence of azide (Figure 2). It is worth mentioning that even L-carnosine, a compound that is being extensively studied due to its ability to prevent protein damage and cross-linkings

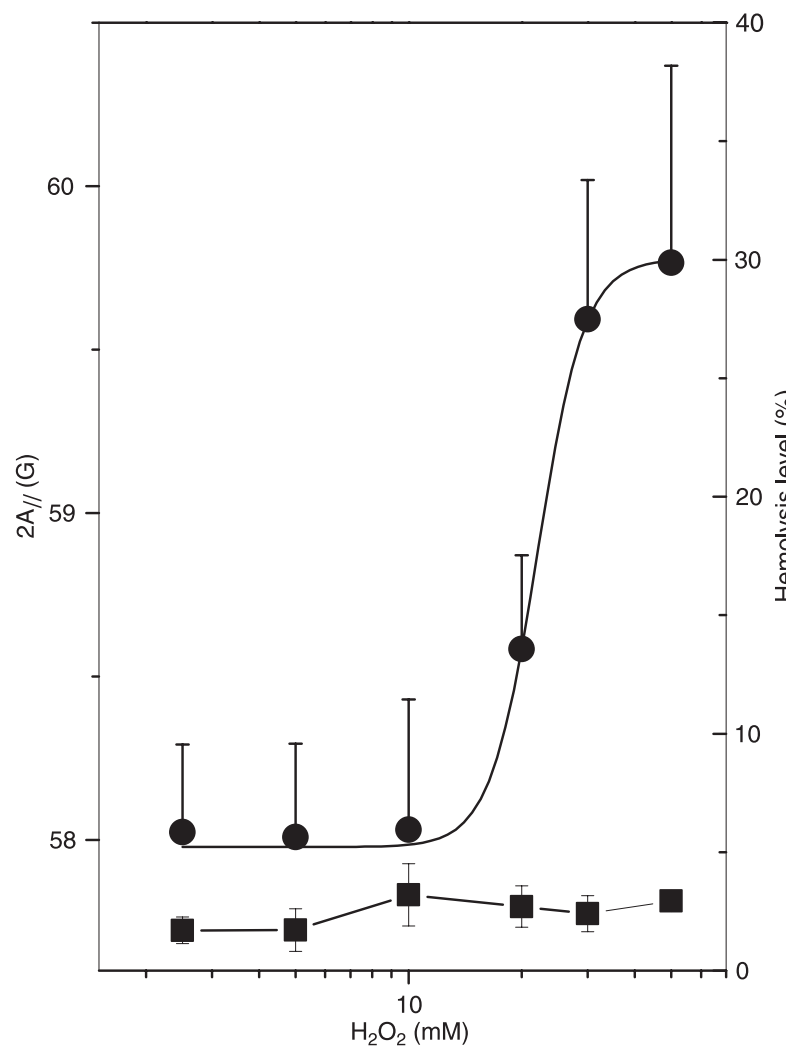

Figure 6. Electron magnetic resonance parameter, $2 A_{/ /}$, of 5-doxyl stearic acid in erythrocyte membranes (circles) and oxidative hemolytic level (squares) plotted against $\mathrm{H}_{2} \mathrm{O}_{2}$ concentration for samples with no inhibition of catalase present in the erythrocyte. mediated by agents such as MDA (the lipid peroxidation product) (29), had no protective effect against the membrane rigidity induced by $\mathrm{H}_{2} \mathrm{O}_{2}$ oxidation (data not shown).

Because $\mathrm{H}_{2} \mathrm{O}_{2}$ induces damage on the erythrocyte membrane that cannot be prevented by classical antioxidants, probably due to the high amount of iron present in the erythrocyte, we conducted an experiment using ghost membranes with the addition of iron sulfate and $\mathrm{H}_{2} \mathrm{O}_{2}$. The EPR parameter, $2 A_{/ /}$, for 5-DSA indicated a less pronounced effect of membrane rigidity (Figure 7) and $100 \mu \mathrm{M}(+)$-catechin was able to protect the membrane against alterations in rigidity. TBARS production (Figure 7 ) also showed the protective effect of $(+)$-catechin on the ghost membranes.

A

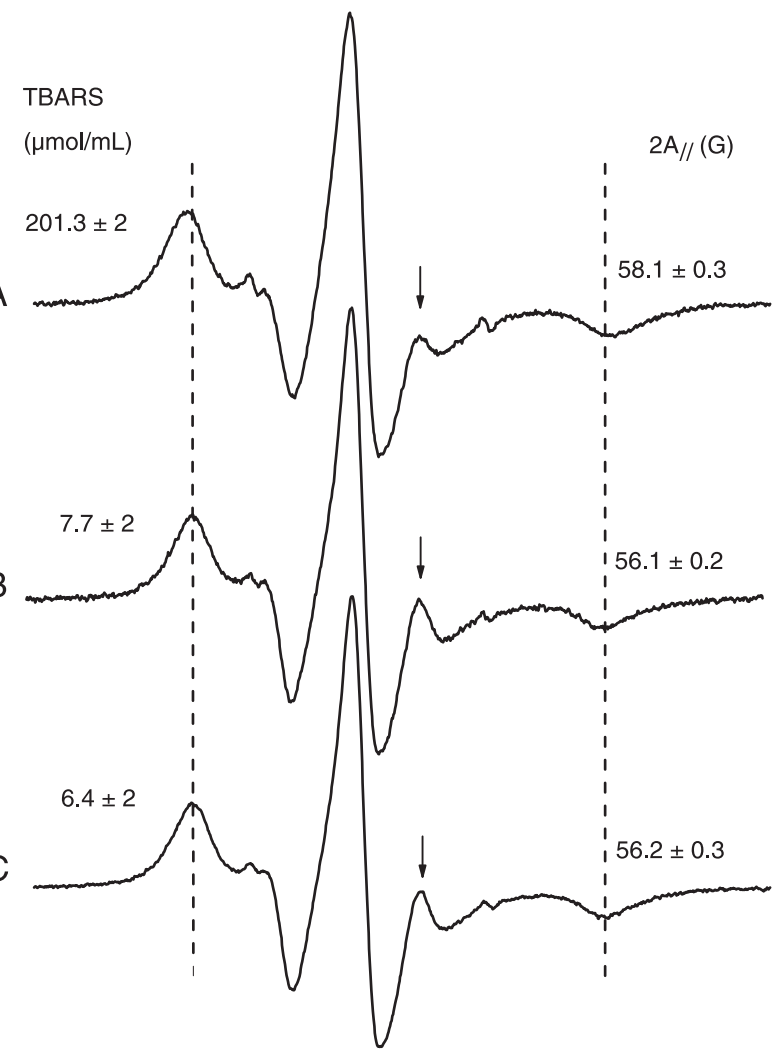

Figure 7. $A$, Electron magnetic resonance (EPR) spectrum of 5-doxyl stearic acid in erythrocyte ghosts oxidized with $2 \mathrm{mM}$ $\mathrm{H}_{2} \mathrm{O}_{2}$ and $200 \mu \mathrm{M} \mathrm{FeSO}_{4}$. B, Control sample (not oxidized). C, Samples pre-treated with $100 \mu \mathrm{M}(+)$-catechin and then oxidized as in $A$. The EPR parameter, $2 \mathrm{~A}_{/ /}$, increases for the oxidized sample, indicating a reduction in molecular dynamics or increased molecular order. The high-field resonance line of the inner hyperfine splitting (indicated by an arrow for each spectrum) decreases in the spectrum of oxidized membranes, indicating a loss of probe mobility. The figure also shows a decrease in the production of thiobarbituric acid reactive species (TBARS) resulting from lipid peroxidation of erythrocyte ghosts due to the antioxidant activity of $(+)$-catechin. 


\section{Discussion}

In the current study, the membrane dynamic changes in erythrocytes subjected to oxidative stress with $\mathrm{H}_{2} \mathrm{O}_{2}$ were characterized by EPR spectroscopy using spin labels specific for both lipid and protein components. Interestingly, the lipid spin label 5-DSA was able to detect the alterations in the protein component of the membrane caused by the binding of $\mathrm{Hb}$ to erythrocyte membranes. The EPR spectra of lipid spin labels in lipid bilayers containing proteins are generally composed of two spectral components, a fact indicating the coexistence of two populations of spin labels differing in their state of mobility. The more restricted component is associated with the boundary lipids where the spin labels surround the hydrophobic regions of proteins, whereas the more mobile component arises from the spin labels located in the bulk bilayer phase, away from the protein $(24,25)$. However, probably due to the high protein concentrations in the erythrocyte membrane ( $50 \%)$, only the spectral component corresponding to the spin label contacting proteins appears in the EPR spectra of 5-DSA, indicating that the fraction of spin labels without any contact with proteins is too small. Thus, a spin-labeled lipid may detect changes in the protein component of RBC membranes. For oxidized samples of RBC ghosts, increases in the $2 A_{/ /}$parameter of up to about $2 \mathrm{G}$ were observed (Figure 7). For erythrocyte membranes, in which protein binding occurs in the membrane upon oxidation with $\mathrm{H}_{2} \mathrm{O}_{2}$, the observed increases were about $5 \mathrm{G}$ (Figure $2 B$ ). Equivalent increases of the $2 A_{/ /}$parameter (2 and $5 \mathrm{G}$ ) could be achieved by lowering the temperature of the non-oxidized membrane by about $8^{\circ}$ and $20^{\circ} \mathrm{C}$, respectively (30).

Several studies have assessed the degree of lipid peroxidation using EPR spectroscopy of spin-labeled lipids incorporated into membranes. For instance, the chilling stress in coffee seedlings caused by plant exposure to a temperature of $10^{\circ} \mathrm{C}$ for 6 days in darkness led to membrane stiffness of the plant root, which was associated with growth inhibition, changes in metabolic rates and MDA formation and was interpreted to be due to lipid peroxidation $(12,13)$. The increase in the $2 A_{/ /}$parameter of 5-DSAmeasured directly in intact root-tip segments was about $2 \mathrm{G}$ for coffee seedlings exposed to chilling stress. Similar increases in $2 A_{/ /}$were caused by iron-induced lipoperoxidation in mitochondrial membranes, which was prevented by $25 \mu \mathrm{M}$ dipyridamole, a coronary vasodilator (14). These data are consistent with the increase of about $2 \mathrm{G}$ in the $2 \mathrm{~A}_{/ /}$parameter, observed here for ghost membranes, which was caused by lipid peroxidation with $\mathrm{Fe}^{2+}$ plus $\mathrm{H}_{2} \mathrm{O}_{2}$. In the membrane model of sonicated soybean phospholipid vesicles, the effect of lipid peroxidation with iron/ascorbate on membrane fluidity was dependent on the nitroxide position along the fatty-acid chain. Maximum rigidity was observed for the positional isomers 10- and 12-DSA (16).
Oxidative stress on the protein component of cell membranes has been monitored by EPR spectroscopy of spin-labeled maleimide in several studies, indicating that the spectral intensity ratio, W/S, may be a general index of oxidative injury to membrane proteins (17-19). For instance, it has been reported that oxidative stress induced by iron/ ascorbate on the rodent synaptosome membrane causes stiffness in the protein component as judged by the EPR parameter W/S from a thiol-selective spin-label (18). In the present study, we show that another more important spectral parameter, $2 A_{/ /}$, directly related to the dynamics of the protein backbone, also indicates stiffening when the proteins are oxidized. Here, the variation of $2 \mathrm{~A}_{/ /}$for $5-\mathrm{MSL}$ in erythrocyte membranes oxidatively stressed by $\mathrm{H}_{2} \mathrm{O}_{2}$ was $1 \mathrm{G}$ (Figure 4B), which is only half the variation observed with the spin-labeled lipid in RBC ghosts (Figure 7). The experimental error of $2 \mathrm{~A}_{/ /}$is $0.5 \mathrm{G}$, but the high reproducibility of the EPR technique allowed us to obtain a curve and significant differences. EPR spectroscopy also allows an assessment of the amount of free sulfhydryl groups in the sample that is proportional to the signal intensity of thiolspecific spin labels. The amount of accessible $\mathrm{SH}$ groups gradually increased with $\mathrm{H}_{2} \mathrm{O}_{2}$ concentration in RBCs, suggesting that proteins, possibly $\mathrm{Hb}$ molecules, bind to the membrane during oxidative stress and contribute additional $\mathrm{SH}$ groups. The amount of free thiol groups in the erythrocyte membrane correlated with the membrane's protein content and degree of rigidity in the $\mathrm{H}_{2} \mathrm{O}_{2}$-concentration range of 50 to $200 \mu \mathrm{M}$ (Figure 5). A decrease in the number of free $\mathrm{SH}$ groups was observed for concentrations of 300 to 1500 $\mu \mathrm{M}$, the same concentration range at which the hemolytic and TBARS levels were increased. These results suggest that during the process of lipid peroxidation the $\mathrm{SH}$ groups are oxidized, in agreement with complementary studies showing that the $\mathrm{SH}$ group content in erythrocyte ghosts decreases with lipid peroxidation by $\mathrm{H}_{2} \mathrm{O}_{2}$ (19).

Snyder et al. (5) showed that $\mathrm{H}_{2} \mathrm{O}_{2}$ induces the formation of a spectrin- $\mathrm{Hb}$ complex in human erythrocyte membranes associated with a progressive alteration in the cell's shape to echinocytic morphology, decreased cell deformability and increased phagocytosis. The authors pointed out that the role of heme proteins is crucial for the occurrence of these cellular changes because they can be completely inhibited by prior exposure of erythrocytes to carbon monoxide. Lipid peroxidation does not appear to be important because the antioxidant butylated hydroxytoluene was only able to inhibit lipoperoxidation, while failing to prevent the formation of the spectrin-Hb complex (5). In addition, Aydogan et al. (31) showed that L-carnosine significantly improved the RBC deformability, which is impaired by $\mathrm{H}_{2} \mathrm{O}_{2}$-induced oxidative stress. In our experiments, the antioxidants ascorbic acid and $\alpha$-tocopherol prevented oxidative hemolysis and TBARS production, but neither they nor L-carnosine were able to prevent large increases in membrane rigidity observed when RBCs were exposed to $\mathrm{H}_{2} \mathrm{O}_{2}$. 
These results suggest that the oxidative hemolysis measured here was due to lipid peroxidation and that the antioxidants acted only as free radical scavengers. Similarly, the antioxidant (+)-catechin also prevented membrane rigidity and TBARS production in erythrocyte ghosts induced by the Fenton reaction but was unable to inhibit damage to the intact erythrocyte. Thus, catalase seems to be the only antioxidant able to prevent alterations in the erythrocyte membrane dynamics when oxidative stress is triggered by hydrogen peroxide in the presence of hemoglobin. In fact, oxidative damage to RBCs during refrigerated storage has been well documented $(23,32)$ and recently, the probable formation of non-reducible cross-linkings of oxidized/denatured $\mathrm{Hb}$ or hemichromes was detected with RBC membranes (23). The present study highlights the role of catalase in protecting $\mathrm{RBC}$ against exogenous hydrogen peroxide. Although azide has been widely used as an inhibitor of catalase in RBC, its specificity needs to be further investigated. Along with catalase, hydrogen peroxide is also decomposed by glutathione peroxidase and cytoplasmic peroxiredoxins. Furthermore, it has been reported that peroxiredoxin 2 , the third most abundant protein in erythrocytes, appears to play an important role in the metabolism of low-level hydrogen peroxide in the erythrocyte (33-35).

In conclusion, the present study showed that EPR spectroscopy of a spin-labeled lipid is highly sensitive to the binding of oxidized $\mathrm{Hb}$ to the membrane when RBCs are subjected to oxidative stress with $\mathrm{H}_{2} \mathrm{O}_{2}$. The increase

\section{References}

1. Cimen MY. Free radical metabolism in human erythrocytes. Clin Chim Acta 2008; 390: 1-11.

2. Nikoliæ-Kokiæ A, Blagojeviæ D, Spasiæ MB. Complexity of free radical metabolism in human erythrocytes. $J$ Med Biochem 2010; 29: 189-195.

3. Sadrzadeh SM, Graf E, Panter SS, Hallaway PE, Eaton JW. Hemoglobin. A biologic fenton reagent. J Biol Chem 1984; 259: 14354-14356.

4. Tedesco I, Russo M, Russo P, lacomino G, Russo GL, Carraturo $A$, et al. Antioxidant effect of red wine polyphenols on red blood cells. J Nutr Biochem 2000; 11: 114-119.

5. Snyder LM, Fortier NL, Trainor J, Jacobs J, Leb L, Lubin B, et al. Effect of hydrogen peroxide exposure on normal human erythrocyte deformability, morphology, surface characteristics, and spectrin-hemoglobin cross-linking. J Clin Invest 1985; 76: 1971-1977.

6. Girotti AW, Thomas JP. Damaging effects of oxygen radicals on resealed erythrocyte ghosts. J Biol Chem 1984; 259: 1744-1752.

7. Singh N, Rajini PS. Antioxidant-mediated protective effect of potato peel extract in erythrocytes against oxidative damage. Chem Biol Interact 2008; 173: 97-104.

8. Davies KJ. Protein damage and degradation by oxygen radicals. I. General aspects. J Biol Chem 1987; 262: 9895- in membrane rigidity caused by this oxidation process was also detected by a thiol-specific spin label, which allowed us to quantify the free sulfhydryl groups. The amount of accessible thiol groups correlated with the protein content of the erythrocyte membrane and with the membrane rigidity at low $\mathrm{H}_{2} \mathrm{O}_{2}$ concentrations. At higher $\mathrm{H}_{2} \mathrm{O}_{2}$ concentrations $(0.4 \mathrm{mM})$, there is oxidation of $\mathrm{SH}$ groups. Hemolysis and TBARS formation, observed for higher $\mathrm{H}_{2} \mathrm{O}_{2}$ concentrations, was inhibited by ascorbic acid and a-tocopherol, but these antioxidants, as well as L-carnosine and (+)-catechin, were unable to prevent the membrane rigidity, which occurs even for low $\mathrm{H}_{2} \mathrm{O}_{2}$ concentrations and short incubation periods. Moreover, a reduction in the fluidity of erythrocyte ghosts induced by the Fenton reaction was inhibited by the antioxidant (+)-catechin. We also showed that EPR spectroscopy can be useful to assess the molecular dynamics of RBC membranes in both the lipid and protein domains, and thus examine the oxidation processes in a system that is so vulnerable to oxidation.

\section{Acknowledgments}

The authors are grateful to INGOH - Goiano Institute of Oncology and Hematology and Hemolabor - Clinical Analysis Laboratories for the blood supply. Research supported by CNPq, CAPES and FUNAPE. S.A. Mendanha, J.L.V. Anjos and A.H.M. Silva are recipients of fellowships from CAPES. A. Alonso gratefully acknowledges CNPq for a research grant.
9901.

9. Halder J, Bhaduri AN. Protective role of black tea against oxidative damage of human red blood cells. Biochem Biophys Res Commun 1998; 244: 903-907.

10. Durak I, Kavutcu M, Çimen MY, Avcý A, Elgün S, Öztürk HS. Oxidant/antioxidant status of erythrocytes from patients with chronic renal failure: effects of hemodialysis. Med Princ Pract 2001; 10: 187-190.

11. Ajila CM, Prasada Rao UJ. Protection against hydrogen peroxide induced oxidative damage in rat erythrocytes by Mangifera indica L. peel extract. Food Chem Toxicol 2008; 46: 303-309.

12. Alonso A, Queiroz CS, Magalhaes AC. Chilling stress leads to increased cell membrane rigidity in roots of coffee (Coffea arabica L.) seedlings. Biochim Biophys Acta 1997; 1323: 75-84.

13. Queiroz CGS, Alonso A, Mares-Guia M, Magalhães AC. Chilling-induced changes in membrane fluidity and antioxidant enzyme activities in Coffea arabica L. roots. Biol Plantarum 1998; 41: 403-413.

14. Nepomuceno MF, Alonso A, Pereira-da-Silva L, Tabak M. Inhibitory effect of dipyridamole and its derivatives on lipid peroxidation in mitochondria. Free Radic Biol Med 1997; 23: 1046-1054. 
15. Chen L, Yang $X$, Jiao H, Zhao B. Tea catechins protect against lead-induced cytotoxicity, lipid peroxidation, and membrane fluidity in HepG2 cells. Toxicol Sci 2002; 69: 149-156.

16. Bruch RC, Thayer WS. Differential effect of lipid peroxidation on membrane fluidity as determined by electron spin resonance probes. Biochim Biophys Acta 1983; 733: 216-222.

17. Trad $\mathrm{CH}$, Butterfield DA. Menadione-induced cytotoxicity effects on human erythrocyte membranes studied by electron paramagnetic resonance. Toxicol Lett 1994; 73: 145-155.

18. Hensley K, Carney J, Hall N, Shaw W, Butterfield DA. Electron paramagnetic resonance investigations of free radicalinduced alterations in neocortical synaptosomal membrane protein infrastructure. Free Radic Biol Med 1994; 17: 321331.

19. Soszynski M, Bartosz G. Decrease in accessible thiols as an index of oxidative damage to membrane proteins. Free Radic Biol Med 1997; 23: 463-469.

20. Gilbert HS, Stump DD, Roth EF Jr. A method to correct for errors caused by generation of interfering compounds during erythrocyte lipid peroxidation. Anal Biochem 1984; 137 : 282-286.

21. Walker JM. The protein protocols handbook. Totowa: Humana Press Inc.; 2002.

22. Smith PK, Krohn RI, Hermanson GT, Mallia AK, Gartner $\mathrm{FH}$, Provenzano MD, et al. Measurement of protein using bicinchoninic acid. Anal Biochem 1985; 150: 76-85.

23. Kriebardis AG, Antonelou MH, Stamoulis KE, EconomouPetersen E, Margaritis LH, Papassideri IS. Progressive oxidation of cytoskeletal proteins and accumulation of denatured hemoglobin in stored red cells. J Cell Mol Med 2007; 11: 148-155.

24. Jost PC, Griffith OH, Capaldi RA, Vanderkooi G. Evidence for boundary lipid in membranes. Proc Natl Acad Sci U S A 1973; 70: 480-484.

25. Griffith $\mathrm{OH}$, Jost PC. Lipid spin labels in biological mem- branes. In: Berliner LJ (Editor), Spin labeling: theory and application. New York: Academic Press; 1976. p 454-523.

26. Alonso A, Goncalves dos SJ, Tabak M. Stratum corneum protein mobility as evaluated by a spin label maleimide derivative. Biochim Biophys Acta 2000; 1478: 89-101.

27. Alonso A, Vasques da Silva J, Tabak M. Hydration effects on the protein dynamics in stratum corneum as evaluated by EPR spectroscopy. Biochim Biophys Acta 2003; 1646: 32-41.

28. Alonso A, dos Santos WP, Leonor SJ, dos Santos JG, Tabak M. Stratum corneum protein dynamics as evaluated by a spin-label maleimide derivative: effect of urea. Biophys $J$ 2001; 81: 3566-3576.

29. Hipkiss AR, Preston JE, Himswoth DT, Worthington VC, Abbot NJ. Protective effects of carnosine against malondialdehyde-induced toxicity towards cultured rat brain endothelial cells. Neurosci Lett 1997; 238: 135-138.

30. Alonso A, Meirelles NC, Tabak M. Effect of hydration upon the fluidity of intercellular membranes of stratum corneum: an EPR study. Biochim Biophys Acta 1995; 1237: 6-15.

31. Aydogan S, Yapislar H, Artis S, Aydogan B. Impaired erythrocytes deformability in $\mathrm{H}_{2} \mathrm{O}_{2}$-induced oxidative stress: protective effect of L-carnosine. Clin Hemorheol Microcirc 2008; 39: 93-98.

32. Yoshida T, Shevkoplyas SS. Anaerobic storage of red blood cells. Blood Transfus 2010; 8: 220-236.

33. Low FM, Hampton MB, Winterbourn CC. Peroxiredoxin 2 and peroxide metabolism in the erythrocyte. Antioxid Redox Signal 2008; 10: 1621-1630.

34. Manta B, Hugo M, Ortiz C, Ferrer-Sueta G, Trujillo M, Denicola $A$. The peroxidase and peroxynitrite reductase activity of human erythrocyte peroxiredoxin 2. Arch Biochem Biophys 2009; 484: 146-154.

35. Winterbourn CC, Hampton MB. Thiol chemistry and specificity in redox signaling. Free Radic Biol Med 2008; 45: 549561. 